\title{
A new record of the indo-Pacific Whitespotted surgeonfish, Acanthurus guttatus, in the eastern tropical Pacific (Isla del Coco, Costa Rica)
}

\author{
Marta Cambra ${ }^{1 *}$, Roberto Cubero², Isaac Chinchilla² and Juan Carlos Azofeifa-Solano ${ }^{3,4}$
}

\begin{abstract}
Background: Acanthurus guttatus is distributed from the Maldives to the Hawaiian Archipelago and the Pitcairn Islands, and as north as Ryukyu Islands and as south as New Caledonia. The only known locality in the Eastern Tropical Pacific is Clipperton Atoll where three vagrant specimens have been observed.

Methods: On June 2016 and April 2017 small groups of A. guttatus were observed and photographed during SCUBA diving and snorkeling surveys for touristic suitability at Isla del Coco National Park, Costa Rica.

Results: Six specimens of A. guttatus were observed swimming over shallow rocky reefs at Isla del Coco, a volcanic island located in the Eastern Tropical Pacific.

Conclusions: This study represents the first record of A. guttatus at Isla del Coco, the second known location of occurrence in the Eastern Tropical Pacific, and the easternmost known range for the Whitespotted surgeonfish.

Keywords: Acanthuridae, Cocos Island, Coral reefs, Costa Rica, East Pacific Barrier, First record, Oceanic island, Reef fish diversity
\end{abstract}

\section{Background}

The East Pacific Barrier (EPB) has long been considered one of the greatest obstructions to the dispersal of marine shallow-dwelling species (Ekman, 1953; Mayr, 1954; Briggs, 1961; Grigg \& Hey, 1992; Robertson et al., 2004). This is a large extension of deep-waters arising from the Line Islands (Central Pacific) to Clipperton Atoll (Eastern Tropical Pacific), without any islands or shallow waters for about 4000 km to 7000 km (Ekman, 1953; Briggs, 1961; Robertson et al., 2004). The EPB has been widely acknowledged in contributing to the remarkable differentiation between the fauna from both sides of the Pacific basin (Ekman, 1953; Vermeij, 1987; Emerson, 1982). However, further revisions have found that several taxonomic groups share species distributed at both Indo-Pacific and Eastern Tropical Pacific (ETP) regions: corals (Dana, 1975; Glynn \& Wellington,

\footnotetext{
*Correspondence: m.cambra.agusti@gmail.com

'Área de Conservación Marina Isla del Coco, Sistema Nacional de Áreas de Conservación, San José, Costa Rica

Full list of author information is available at the end of the article
}

1983; Cortés, 1986; Grigg \& Hey, 1992; Glynn \& Ault, 2000), crustaceans (Chase Jr., 1942; Garth, 1965, 1974; Holthuis \& Loesch, 1967; Wicksten \& Hendrickx, 2003), mollusks (Emerson, 1967, 1978, 1982; Vermeij, 1987), echinoderms (Nishida \& Lucas, 1988; Lessios et al., 1996) and fishes (Rosenblatt et al., 1972; Briggs, 1974; Leis, 1983; Robertson et al., 2004; Robertson \& Allen, 2015).

Isla del Coco (also known as Cocos Island) is one of the five oceanic islands in the ETP and is widely recognized as a hotspot of marine biodiversity (Cortés, 2008, 2012, 2016). It is also considered one of the most effective and successful Marine Protected Areas worldwide, due to its isolation, extension, degree of enforcement, time since creation and a complete ban on fishing activities (Edgar et al., 2014). The fish fauna had been extensively studied since Garman (1899), and then by several expeditions and studies (see Fourriére et al., 2016). Recent contributions on fish fauna knowledge of Isla del Coco are Bussing and López (2005, 2009), Garrison (2005), and Cortés (2012). The most updated and detailed list of the fish species for 
Isla del Coco was provided by Fourriére et al. (2016), who reports 514 species. The island and its surrounding waters support $\sim 39 \%$ and $\sim 56 \%$ of the reported fish species for the ETP and Costa Rica, respectively (Cortés, 2012; Robertson \& Allen, 2015; Fourriére et al., 2016).

The Indo-Pacific Whitespotted surgeonfish, Acanthurus guttatus Forster, 1901, is widely distributed in the IndoPacific region at the Hawaiian Archipelago, Pitcairn Islands, to the west to the Maldive Islands, Chagos Archipelago, Mascarenes, Seychelles, to the north to the Ryukyu Islands, south to the Great Barrier Reef, Australia and New Caledonia (Abesamis et al., 2012; Fig. 1), occurring mainly in the surge zone of clear seaward reefs (Lieske \& Myers 1994). This specie was reported for the first time in the ETP at Clipperton Atoll, the only known location for this species in the ETP (Bearez \& Séret, 2009; Fourriére et al., 2014). The present report details the first record of A. guttatus in Isla del Coco, a new location of this species in the ETP, and the easternmost extension of the species.

\section{Methods}

A total of six specimens of $A$. guttatus were observed at two different locations in Isla del Coco during different times. Two specimens were observed on June 13th 2016 at 16:04 $\mathrm{h}$ during a scuba-diving survey, 5-8 $\mathrm{m}$ depth, at El Arco ( $5^{\circ} 31^{\prime} 53.22^{\prime \prime} \mathrm{N}$; 87 $\left.81^{\circ} 37.86^{\prime \prime} \mathrm{W}\right)$ located on the east side of Isla del Coco (Fig. 1). A video was recorded showing the two specimens. A grab from the video is shown in Fig. 2a. Four specimens were observed swimming together during a snorkeling survey at $4 \mathrm{~m}$ depth on April 12th 2017 at 09:20 h at Bahía Porites (5³1'33.96"N; $87^{\circ} 05^{\prime} 32.28^{\prime \prime} \mathrm{W}$ ) in the west side of Isla del Coco (Figs. 1 and $2 \mathrm{~b}$ ). The sites were characterized as shallow rocky reefs next to coral reef areas dominated by Porites lobata (Dana, 1846). The identification was made following Robertson and Allen (2015), and corroborated by Ross Robertson, Smithsonian Tropical Research Institute, Panamá.

\section{Results}

A total of six Whitespotted surgeonfish specimens had been sighted at Isla del Coco between 2016 and 2017. In the first sighting, the two individuals were swimming in a shallow rocky reef, together with other species, Anisotremus interruptus (Gill, 1862), Paranthias colonus (Valenciennes, 1846) and Prionurus laticlavius (Valenciennes, 1846).

The observed fishes and the photographs display the morphological characteristics that allow the identification of this reef fish (Fig. 2). These characteristics are: an ovalshaped gray body with two white bars, and many little white spots on the posterior body, as described by Robertson and Allen (2015). These characteristics differentiate $A$. guttatus from other similar surgeonfishes occurring in the ETP such as Acanthurus achilles (Shaw, 1803), Acanthurus nigricans (Linnaeus, 1758), Acanthurus triostegus (Linnaeus, 1758), Acanthurus xanthopterus (Valenciennes, 1835), and Ctenochaetus marginatus (Valenciennes, 1835).

\section{Discussion}

This report represents the easternmost recorded range of A. guttatus (Fig. 1). Previous to this record, Clipperton Atoll was the easternmost known range (Bearez \&

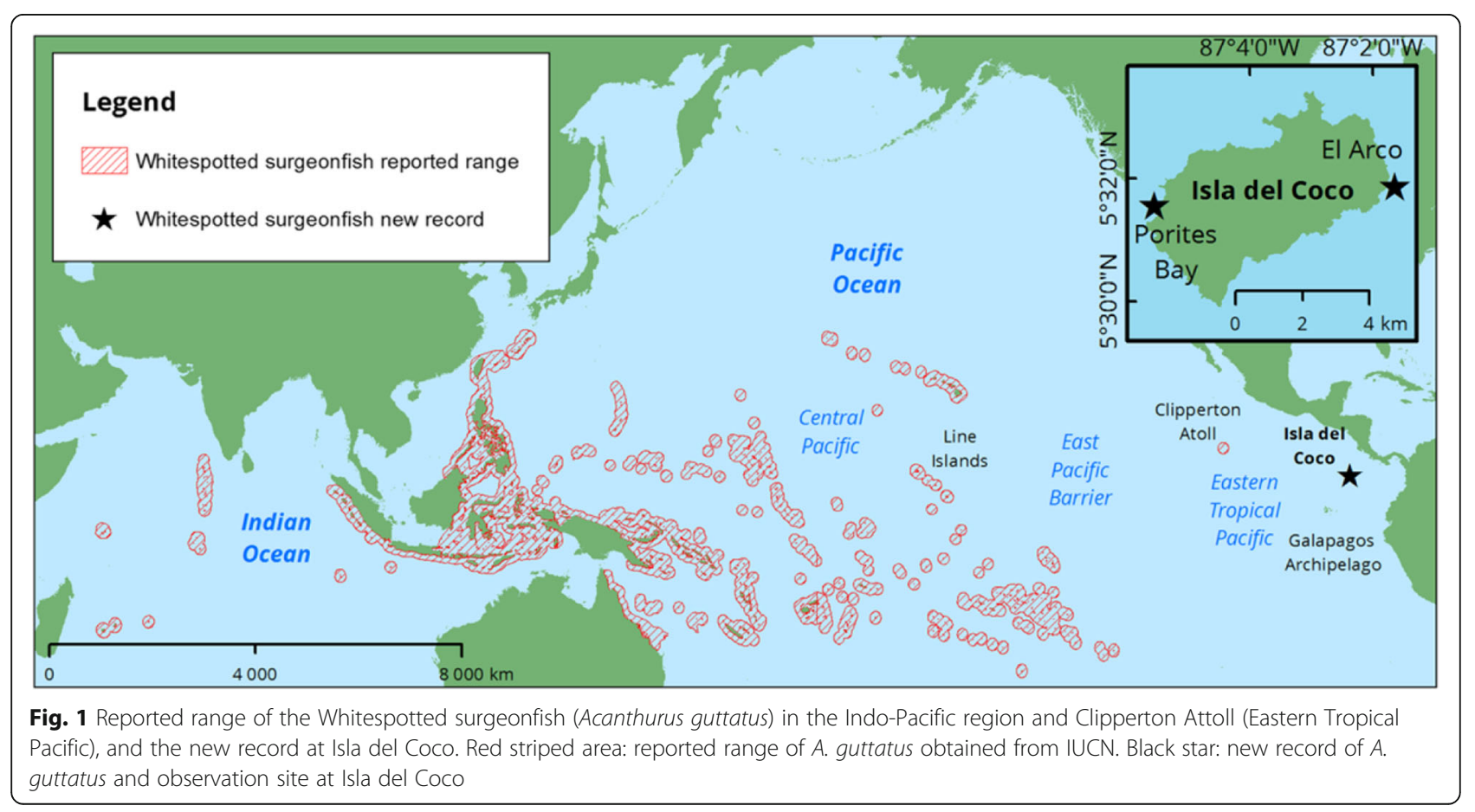



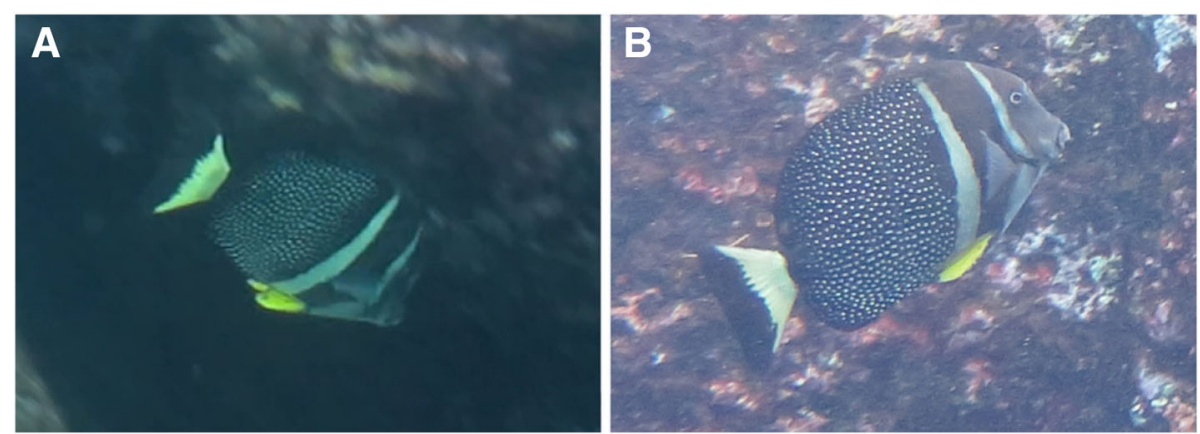

Fig. 2 Acanthurus guttatus observed swimming at Isla del Coco, Eastern Tropical Pacific. a Grab from a video featuring A. guttatus at El Arco (5-8 m depth), June 13th 2016. b Photograph of A. guttatus at Porites Bay (4 m depth), April12th 2017. Credits: Fig. 2a Marta Cambra, and 2B Roberto Cubero

Séret, 2009; Fourriére et al., 2014, Fig. 1), where three adults were observed (one collected) in March 2005. This species was not previously observed at Clipperton Atoll during two expeditions in 1994 and 1998, and is considered a vagrant in the ETP (Robertson \& Allen 2015). Before being recorded in the ETP, A. guttatus eastward range was the Hawaiian Archipelago and Pitcairn Islands (Abesamis et al. 2012; Fig. 1).

This study represents a new record for Isla del Coco and a novel addition to its coral reef fish diversity. Acanthurus guttatus was not previously recorded during recent expeditions and studies on the fishes of Isla del Coco (Busing \& López, 2009; Cortés, 2012; Friedlander et al., 2012; Alvarado et al., 2016; Fourriére et al., 2016). An analysis of completeness of the fish inventory at Isla del Coco showed that about $93.7 \%$ of the fish species richness is known, and therefore, around 20 species are still to be discovered (Fourriére et al., 2016). The Whitespotted surgeonfish is a remarkable and conspicuous reef fish, and it is hardly probable that it was present during previous fish surveys. Therefore, we suggest that A. guttatus is probably a recent vagrant at the island.

Acanthuridae is considered among the tropical fish families with high proportion of vagrant species (Feary et al., 2013). Briggs (1961) reported four species of surgeonfish with a transpacific distribution. Genetic connection studies of two surgeonfish species and 18 other transpacific species, also indicate that EPB is sporadically permeable (Lessios \& Robertson, 2006). Further revisions have revealed that from the 13 species of Acanthuridae reported at the ETP, 11 have a transpacific distribution (Robertson et al., 2004; Bearez \& Séret, 2009; Robertson \& Allen, 2015).

Larval duration is thought to play an important role in species dispersal ability (Lester and Ruttenberg, 2005). The spiny acronurus larvae of some surgeonfish have pelagic larval durations up to $>100$ days (Briggs, 1961; Robertson et al., 2004). Several studies had demonstrated the high dispersal ability of the genus Acanthurus (Eble et al., 2011, DiBattista et al.
2016). We suspect that the specimens observed in Isla del Coco may have crossed the East Pacific Barrier during early stages of development.

Oceans currents can have a strong influence on population connectivity (White et al. 2010). Isla del Coco is located at an area seasonally influenced by the Pacific North Equatorial Countercurrent (NECC) from May to October, which intensifies during $\mathrm{El}$ Niño phenomena (Lizano, 2008). A stronger Pacific NECC can enhance the eastward dispersal of marine larvae, including those of tropical reef fishes (Glynn \& Ault, 2000; Robertson, 2001; Hickman, 2009; Acuña-Marrero \& Salinas-De-León, 2013). Craig (2008) associated eastward dispersal of a surgeonfish species from the western Indian Ocean to Chagos via direct larval transport during El Niño phenomena. A strong El Niño 2014-2016 event, known as El Niño Godzilla, was a 14 month warming of the Pacific Ocean (Kintisch, 2016). We suggest that the vagrant A. guttatus found at Isla del Coco in June 2016 and April 2017 were most likely transported as larvae from the Indo-Pacific region to the ETP by a strong Pacific NECC during El Niño Godzilla. Further records at Clipperton Atoll and Isla del Coco, along with genetic analyses could reveal the precedence of the specimens at Isla del Coco.

\section{Conclusions}

This finding increases the reported reef fish diversity at Isla del Coco and reveals an eastwards expansion of $A$. guttatus geographical range of distribution. This indicates that the Eastern Pacific Barrier (EPB) is permeable to occasional migrations, particularly from west to east, likely due to strong El Niño events which magnify the action of the Pacific NECC. Given that this specie has not been recorded in Clipperton Atoll since 2005 and that there is no evidence of reproductive populations in the ETP, we propose that A. guttatus is considered a 
vagrant species in Isla del Coco, until reproductive populations are observed.

\section{Acknowledgements}

We are very grateful to Área de Conservación Marina Isla del Coco (ACMIC) for all their support during the fieldwork of this study. We thank Ross Robertson for the corroboration of the species. We would like to thank Jorge Cortés and Marco Corrales-Ugalde for their comments on the manuscript. We are grateful to the IUCN Red List and Instituto Tecnológico de Costa Rica for providing the geographic information of the A. guttatus known distribution and the Costa Rican territory, respectively.

\section{Funding}

The surveys were possible with the financial support of Área de Conservación Marina Isla del Coco (ACMIC).

\section{Availability of data and materials}

Not applicable.

\section{Authors' contributions}

$M C, R C$ and IC performed the monitoring dives which conduct to the finding the new record. $M C$ and $R C$ took the photographs of the specimens and identified the species. JCAS prepare the figures and the map. All authors contributed to draft, read and approve the final manuscript.

\section{Ethics approval and consent to participate}

Not applicable.

\section{Consent for publication}

Not applicable.

\section{Competing interests}

The authors declare that they have no competing interests.

\section{Publisher's Note}

Springer Nature remains neutral with regard to jurisdictional claims in published maps and institutional affiliations.

\section{Author details}

'Área de Conservación Marina Isla del Coco, Sistema Nacional de Áreas de Conservación, San José, Costa Rica. ${ }^{2}$ Parque Nacional Isla del Coco, Área de Conservación Marina Isla del Coco, Sistema Nacional de Áreas de Conservación, San José, Costa Rica. ${ }^{3}$ Programa de Maestría en Biología, Sistema de Estudios de Posgrado, Universidad de Costa Rica, San Pedro, 11,501-2060, San José, Costa Rica. ${ }^{4}$ Centro de Investigación en Ciencias del Mar y Limnología (CIMAR), Ciudad de la Investigación, Universidad de Costa Rica, San Pedro, 11,501, San José -2060, Costa Rica.

\section{Received: 8 January 2018 Accepted: 22 March 2018}

\section{Published online: 10 April 2018}

\section{References}

Abesamis R, Clements KD, Choat JH, Mcllwain J, Myers R, Nanoal C, Rocha LA, Russell B, Stockwell B. Acanthurus guttatus. The IUCN Red List of Threatened Species. 2012. http://www.iucnredlist.org/details/177995/0. Accessed 27 June 2017; https://doi.org/10.2305/IUCN.UK.2012.RLTS.T177995A1515633.en.

Acuña-Marrero D, Salinas-De-León P. New record of two Indo-Pacific reef fish, Caranx ignobilis and Naso annulatus, from the Galapagos Islands. Mar Biodivers Rec. 2013;6:e74. https://doi.org/10.1017/S1755267213000456.

Alvarado JJ, Beita A, Mena S, Fernández-García C, Guzman-Mora AG, Cortés J. Ecosistemas coralinos del Parque Nacional Isla del Coco, Costa Rica: estructura y comparación 1987-2014. Rev. Biol Trop. 2016;64(Supl 1):S153-75.

Bearez P, Séret B. Clipperton, environnement et biodiversité d'un microcosme océanique. Patrimoines Naturels. 2009;68:143-54.

Briggs JC. The East Pacific Barrier and the distribution of marine shore fishes. Evolution. 1961;15:545-54. https://doi.org/10.2307/2406322.

Briggs JC. Operation of zoogeographic barriers. Syst Zool. 1974;23:248-56. https:// doi.org/10.2307/2412136.

Bussing WA, López M. Peces de la Isla del Coco y peces arrecifales de la costa Pacífica de América Central Meridional/Fishes of Cocos Island and
Reef Fishes of the Pacific Coast of Lower Central America. Rev. Biol Trop. 2005;53(Suppl 2):1-192.

Bussing WA, López M. Marine fish. In: Wehrtmann IS, Cortés J, editors. Marine biodiversity of Costa Rica, Central America. Berlin: Springer; 2009. p. 453-8; https://doi.org/10.1007/978-1-4020-82,788.

Chase FA Jr. The non-brachyuran decapod crustaceans of Clipperton Island. Proc US Nat Mus. 1942;113:605-35.

Cortés J. Biogeografía de corales hermatípicos: el istmo centroamericano. Anales del Instituto de Ciencias del Mar y Limnología, Universidad Nacional Autónoma de México. 1986;13:297-304.

Cortés J. Historia de la investigación marina de la Isla del Coco, Costa Rica. Rev. Biol Trop. 2008:56 Suppl 2:1-18.

Cortés J. Marine biodiversity of an Eastern Tropical Pacific oceanic island, Isla del Coco, Costa Rica. Rev. Biol Trop. 2012;60 Suppl 3:131-185.

Cortés J. Isla del Coco: coastal and marine ecosystems. In: Kappelle M, editor. Costa Rican Ecosystems. Chicago and London: University of Chicago Press; 2016. p. 162-91.

Craig MT. (2008). The goldrim surgeonfish (Acanthurus nigricans; Acanthuridae) from Diego Garcia, Chagos Archipelago: first record for the central Indian Ocean. Zootaxa2008., 65 (68),

Dana TF. Development of contemporary Eastern Pacific coral reefs. Mar Biol. 1975;33:355-74. https://doi.org/10.1007/BF00390574.

DiBattista JD, Whitney J, Craig MT, Hobbs JPA, Rocha LA, Feldheim KA, Bowen BW. Surgeons and suture zones: Hybridization among four surgeonfish species in the Indo-Pacific with variable evolutionary outcomes. Molecular phylogenetics and evolution. 2016;101:203-15.

Eble JA, Rocha LA., Craig MT, Bowen BW. Not all larvae stay close to home: insights into marine population connectivity with a focus on the brown surgeonfish (Acanthurus nigrofuscus). Journal of Marine Biology, 2011; Article ID 518516, 12 pgs. https://doi.org/10.1155/2011/518516.

Edgar GJ, Stuart-Smith RD, Willis TJ, Kininmonth S, Baker SC, Banks S, Barrett NS, Becerro MA, ATF B, Berkhout J, Buxton CD, Campbell SJ, Cooper AT, Davey M, Edgar SC, Försterra G, Galván DE, rrigoyen AJ, Kushner DJ, Moura R, Parnell PE, Shears NT, Soler G, EMA S, Thomson RJ. Global conservation outcomes depend on marine protected areas with five key features. Nature. 2014;506: 216-20. https://doi.org/10.1038/nature13022.

Ekman S. Zoogeography of the sea. London: Sidgwick and Jackson; 1953.

Emerson WK. Indo-Pacific elements in the Tropical Eastern Pacific, with special reference to the mollusks. Jap J Malacol. 1967;25:85-93.

Emerson WK. Mollusks with Indo-Pacific faunal affinities in the Eastern Tropical Pacific Ocean. Nautilus. 1978;92:91-6.

Emerson WK. Zoogeographic implications of the occurrence of Indo-Pacific gastropods on the west American continental borderland. West Soc Malacol Ann Rep. 1982:13-4.

Feary DA, Pratchett MS, Emslie MJ, Fowler AM, Figueira WF, Luiz OJ, Nakamura Y, Booth DJ. Latitudinal shifts in coral reef fishes: why some species do and other do not shift. Fish Fish. 2013;15:593-615. https://doi.org/10.1111/faf.12036.

Fourriére M, Alvarado JJ, Ayala A, Cortés J. Updated checklist and analysis of completeness of the marine fish fauna of Isla del Coco. Pacific of Costa Rica Marine Biodiversity. 2016;47:813-21. https://doi.org/10.1007/s12526-016-0501-6.

Fourriére M, Reyes-Bonilla H, Rodríguez-Zaragoza FA, Crane N. Fishes of Clipperton Atoll, Eastern Pacific: checklist, endemism and analysis of completeness of the inventory. Pac Sci. 2014;68:375-95. https://doi.org/10.1111/faf.12036.

Friedlander A, Zgliczynski B, Ballesteros E, Aburto-Oropeza O, Bolaños A, Sala E. The shallow-water fish assemblage of Isla del Coco National Park, Costa Rica: structure and patterns in an isolated, predator-dominated ecosystem. Rev. Biol Trop. 2012;60(Suppl 3):321-38.

Garman S. Reports on an exploration off the west coasts of Mexico, Central and South America, and off the Galapagos Islands, in charge of Alexander Agassiz, by the U.S. Fish Commission Steamer "Albatross", during 1891, Lieut Commander Z.L. Tanner U. S.N., commanding. XXVI. The Fishes Mem Mus Comp Zoöl Harv Coll. 1899;24:1-432.

Garrison G. Peces de la Isla del Coco/Isla del Coco Fishes. 2nd ed. INBio: Heredia; 2005.

Garth JS. The brachyuran decapod Crustaceans of Clipperton Island. Proc Calif Acad Sci. 1965;33:1-46.

Garth JS. On the occurrence in the Eastern Tropical Pacific of Indo-West Pacific decapods crustaceans commensal with reef-building corals. Proceedings of the Second Internation Coral Reef Symposium. 1974;1:397-404.

Glynn PW, Ault JS. A biogeographic analysis and review of the far eastern Pacific coral reef region. Coral Reefs. 2000;19:1-23. https://doi.org/10.1007/ s003380050220. 
Glynn PW, Wellington GM. Corals and coral reefs of the Galápagos Islands. Berkeley: University of California Press; 1983.

Grigg RW, Hey R. Paleoceanography of the Tropical Eastern Pacific ocean. Science. 1992:255:172-8. https://doi.org/10.1126/science.255.5041.172.

Hickman CP Jr. Evolutionary responses of marine invertebrates to insular isolation in Galapagos. Galapagos Res. 2009:66:32-42.

Holthuis LB, Loesch H. The lobsters of the Galápagos Islands (Decapoda, Palinuridea). Crustaceana. 1967;12:214-22.

Kintisch E. How a 'Godzilla' El Niño shook up weather forecasts. Science. 2016; 352:1501-2. https://doi.org/10.1126/science.352.6293.1501.

Leis JM. Coral reef fish larvae (Labridae) in the East Pacific Barrier. Copeia. 1983;3: 826-8. https://doi.org/10.2307/1444356.

Lessios HA, Kessing BD, Wellington GM, Graybeal A. Indo-Pacific echinoids in the Tropical Eastern Pacific. Coral Reefs. 1996;15:133-42. https://doi.org/10.1007/ BF01771904.

Lessios HA, Robertson DR. Crossing the impassable: genetic connections in 20 reef fishes across the eastern Pacific barrier. Proceedings of the Royal Society of London B: Biological Sciences. 2006;273(1598):2201-8.

Lester SE, Ruttenberg BI. The relationship between pelagic larval duration and range size in tropical reef fishes: a synthetic analysis. Proceedings of the Royal Society of London B: Biological Sciences. 2005;272(1563):585-91.

Lieske E, Myers R. Coral reef fishes. Indo-Pacific \& Caribbean including the Red Sea. New York: Harper Collins Publishers; 1994.

Lizano OG. Dinámica de aguas alrededor de la Isla del Coco, Costa Rica. Rev. Biol Trop. 2008;56 Suppl 2:31-48.

Mayr E. Geographic speciation in tropical echinoids. Evolution. 1954;8:1-18. https://doi.org/10.2307/2405661.

Nishida M, Lucas JS. Genetic differences between geographic populations of the crown-of-thorns starfish, throughout the Pacific region. Mar Biol. 1988;98: 359-68. https://doi.org/10.1007/BF00391112.

Robertson DR. Population maintenance among tropical reef fishes: inferences from small-island endemics. Proc Natl Acad Sci USA. 2001;98:5667-70. https://doi.org/10.1073/pnas.091367798.

Robertson DR, Allen GR. Shorefishes of the Tropical Eastern Pacific: online information system. Version 2.0. Smithsonian Tropical Research Institute, Balboa, Panama. 2015. http://www.stri.org/sftep/. Accessed 29 June 2017.

Robertson DR, Grove JS, McCosker JE. Tropical transpacific shore fishes. Pac Sci. 2004;58:507-65.

Rosenblatt RH, McCosker JE, Rubinoff I. Indo-West Pacific fishes from the Gulf of Chiriquí, Panama. Contrib Sci Nat Hist Mus LA Co. 1972;234:1-18.

Vermeij GJ. The dispersal barrier in the Tropical Pacific: implications for molluscan speciation and extinction. Evolution. 1987;41:1046-58. https://doi.org/10. 1111/j.1558-5646.1987.tb05875.x.

White C, Selkoe KA, Watson J, Siegel DA, Zacherl DC, Toonen RJ. Ocean currents help explain population genetic structure: Proceedings of the Royal Society of London B: Biological Sciences; 2010. p. rspb20092214.

Wicksten MK, Hendrickx ME. An updated checklist of benthic marine and brackish water shrimps (Decapoda: Penaeoidea, Stenopodidea, Caridea) from the Eastern Tropical Pacific. In: Hendrickx ME, editor. Contributions to the Study of East Pacific Crustaceans 2. Mexico: Anales del Instituto de Ciencias del Mar y Limnología. UNAM; 2003. p. 49-76.

\section{Submit your next manuscript to BioMed Central and we will help you at every step:}

- We accept pre-submission inquiries

- Our selector tool helps you to find the most relevant journal

- We provide round the clock customer support

- Convenient online submission

- Thorough peer review

- Inclusion in PubMed and all major indexing services

- Maximum visibility for your research

Submit your manuscript at www.biomedcentral.com/submit
Biomed Central 